\title{
Co-intercalated layered double hydroxides as thermal and photo-oxidation stabilizers for polypropylene
}

\author{
Qian Zhang ${ }^{1}$, Qiyu Gu${ }^{1}$, Fabrice Leroux², Pinggui Tang ${ }^{1}$, Dianqing $\mathrm{Li}^{1}$ \\ and Yongjun Feng ${ }^{* 1}$
}

Open Access

\author{
Full Research Paper \\ Address: \\ ${ }^{1}$ State Key Laboratory of Chemical Resource Engineering, Beijing \\ Engineering Center for Hierarchical Catalysts, Beijing University of \\ Chemical Technology, No. 15 Beisanhuan East Road, Beijing \\ 100029, China and 2Université Clermont Auvergne, Institut de Chimie \\ de Clermont-Ferrand ICCF, UMR-CNRS 6296, F 63171 Aubière, \\ France \\ Email: \\ Yongjun Feng ${ }^{*}$ - yjfeng@mail.buct.edu.cn \\ * Corresponding author \\ Keywords: \\ co-intercalation; composites; layered double hydroxides; \\ photo-oxidation stability; polypropylene; thermal stability
}

Beilstein J. Nanotechnol. 2018, 9, 2980-2988.

doi:10.3762/bjnano.9.277

Received: 22 July 2018

Accepted: 16 November 2018

Published: 05 December 2018

This article is part of the thematic issue "Advanced hybrid nanomaterials".

Associate Editor: C. T. Yavuz

(c) 2018 Zhang et al.; licensee Beilstein-Institut. License and terms: see end of document.

\begin{abstract}
An elegant and efficient approach consisting in the co-intercalation of stabilizing molecular anions is described here. The thermal stabilizer calcium diethyl bis[[[3,5-bis(1,1-dimethylethyl)-4-hydroxyphenyl]methyl]phosphonate] (Irganox 1425, MP-Ca) and a photo-oxidation stabilizer (hindered amine light stabilizer, HALS) are co-intercalated into the interlayer regions of layered double hydroxides (LDH) in a one-step coprecipitation. These hybrid organic-inorganic materials are successively dispersed in polypropylene to form $\mathrm{H}_{n} \mathrm{M}_{n^{\prime}}-\mathrm{Ca}_{2} \mathrm{Al} / \mathrm{PP}$ composite films (with $\mathrm{H}=$ HALS and $\mathrm{M}=\mathrm{MP}$ ) through a solvent casting method. The corresponding crystalline structure, chemical composition, morphology as well as the resistance against thermal aging and photo-oxidation are carefully investigated by various techniques. The results show that the powdered $\mathrm{H}_{n} \mathrm{M}_{n^{\prime}} \mathrm{Ca}_{2} \mathrm{Al}-\mathrm{LDH}$ hybrid materials have a much higher thermal stability than MP-Ca and HALS before intercalation. In addition, the $\mathrm{H}_{n} \mathrm{M}_{n^{\prime}}-\mathrm{Ca} 2 \mathrm{Al} / \mathrm{PP}$ composites exhibit a higher overall resistance against thermal degradation and photo-oxidation compared to LDHs intercalated with only HALS or MP. This underlines the benefit of the co-intercalation. The co-intercalated LDH materials pave a new way in designing and fabricating highperformance multifunctional additives for polymers.
\end{abstract}

\section{Introduction}

Hindered phenols and hindered amines, containing the functional groups 2,6-di-tert-butylphenol and 2,2,6,6-tetramethylpiperidine, respectively, are widely used as functional additives in polymers to prolong the service life [1-3]. Generally, the anti- aging agents effectively inhibit the degradation in two ways: (1) through capturing generated free radicals and stopping autooxidation and (2) through decomposing and eliminating hydroperoxides $[4,5]$. However, anti-aging agents are often organic 
chemicals that easily migrate and volatilize from the polymer, reducing the anti-aging efficiency and increasing environmental pollution [6]. Therefore, it is of interest to explore novel multifunctional additives for polymers with high anti-aging performance together with high migration resistance.

Recently, inorganic-organic hybrid functional additives have attracted increasing attention for their wide applications in polymers [7]. Organic anti-aging species have been immobilized onto inorganic supports (e.g., carbon nanotubes, $\mathrm{SiO}_{2}$, graphene oxide) to produce inorganic-organic composites with higher migration resistance [8-10]. More recently, layered double hydroxides (LDHs), a layered host-guest material, have emerged as promising inorganic nanocontainers for functional organic active species to enhance the thermal and photo-oxidation stability of interleaved organic species as well as to endow the polymer/LDH composites with the desired properties [1114]. In our previous work, a series of intercalated antioxidants and photo-oxidation stabilizers with a single active component have been prepared by coprecipitation. In these polymer/LDH compounds, the resistance against aging was significantly improved [15-17]. For example, the antioxidant Irganox 1425 (see Figure 1, abbreviated as MP-Ca) was intercalated into $\mathrm{Ca}_{2} \mathrm{Al}$ $\mathrm{LDH}$ through coprecipitation of MP-Ca and $\mathrm{Al}\left(\mathrm{NO}_{3}\right)_{3}$ at $\mathrm{pH} 10$, to yield MP-Ca 2 Al-LDH. Here, the MP-Ca was used the source of $\mathrm{Ca}$ for the host sheet and that of MP for the guest anions. Polypropylene (PP) protected with the prepared $\mathrm{MP}-\mathrm{Ca}_{2} \mathrm{Al}-$ LDH exhibited enhanced thermal stability and anti-migration behavior in comparison with MP-Ca/PP composites. Lately, some studies have demonstrated much better performance of multi-component intercalation compounds compared to the corresponding single-component intercalation compounds as well as to the physical mixtures of the components $[18,19]$. The benefit of the co-intercalation is attributed to synergistic effects between the different active species associated to a higher dispersion in the composites [20,21].

In this work, we designed and fabricated a series of novel co-intercalated thermal and photo-oxidation stabilizers $\left(\mathrm{H}_{n} \mathrm{M}_{n^{\prime}}\right.$ $\mathrm{Ca}_{2} \mathrm{Al}$ ) through straightforward co-precipitation of HALS and MP-Ca (Figure 1) [16,17], and examined the resistance of the $\mathrm{H}_{n} \mathrm{M}_{n^{\prime}}-\mathrm{Ca}_{2} \mathrm{Al} / \mathrm{PP}$ composites against thermal degradation and photo-oxidation as a function of the molar ratio between HALS and MP in the interlayer regions.

\section{Results and Discussion Analysis of $\mathrm{H}_{n} \mathrm{M}_{n^{\prime}}-\mathrm{Ca}_{2} \mathrm{Al}$-LDHs}

Figure 2 displays powder XRD patterns of $\mathrm{H}_{n} \mathrm{M}_{n^{\prime}}-\mathrm{Ca}_{2} \mathrm{Al}-\mathrm{LDHs}$ with sharp (002), (004) and (006) reflection peaks at low angles and the weaker (110) peak at a higher angle, corresponding to the layered structure and the intra-layer structure in the host

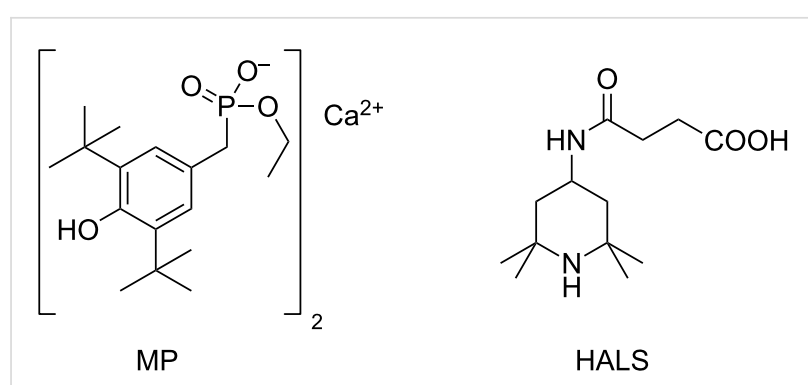

Figure 1: Molecular structures of Irganox 1425 (MP-Ca) and hindered amine light stabilizer (HALS).

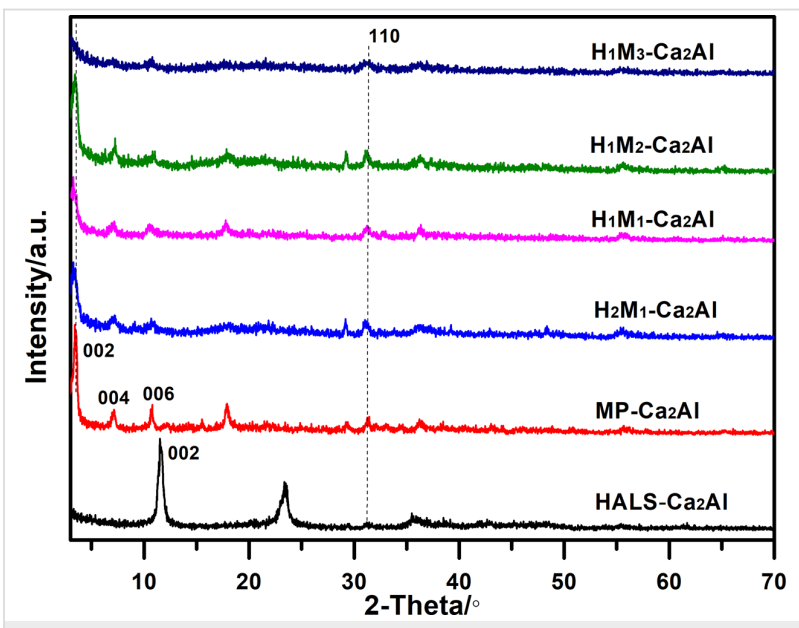

Figure 2: Powder X-ray diffraction patterns of different $\mathrm{H}_{n} \mathrm{M}_{n^{\prime}}-\mathrm{Ca}_{2} \mathrm{Al}-$ LDH samples.

sheet [22]. The (002) reflection peaks of HALS-Ca $\mathrm{Cl}_{2} \mathrm{Al}$ and $\mathrm{MP}-\mathrm{Ca}_{2} \mathrm{Al}$ are located at $11.5^{\circ}\left(d_{002}=0.77 \mathrm{~nm}\right)$ and $3.4^{\circ}$ $\left(d_{002}=2.52 \mathrm{~nm}\right)$, respectively. Simultaneously, for LDHs co-intercalated with HALS and MP $\left(\mathrm{H}_{2} \mathrm{M}_{1}-\mathrm{Ca}_{2} \mathrm{Al}, \mathrm{H}_{1} \mathrm{M}_{1}\right.$ $\left.\mathrm{Ca}_{2} \mathrm{Al}, \mathrm{H}_{1} \mathrm{M}_{2}-\mathrm{Ca}_{2} \mathrm{Al}, \mathrm{H}_{1} \mathrm{M}_{3}-\mathrm{Ca}_{2} \mathrm{Al}\right)$, the (002) reflection peaks appear at ca. $3.4^{\circ}$, corresponding to the $d$-spacing values of $2.55,2.68,2.55$, and $2.75 \mathrm{~nm}$, respectively. The enlarged $d$-spacing of $\mathrm{H}_{n} \mathrm{M}_{n^{\prime}}-\mathrm{Ca}_{2} \mathrm{Al}$-LDHs suggests that HALS and MP anions were co-intercalated into the $\mathrm{LDH}$, and the different ratios of HALS/MP result in a slightly different arrangement of guest anions leading to minor variations of the $d$-spacing values. The full width at half maximum values of the (002) reflection of all $\mathrm{H}_{n} \mathrm{M}_{n^{\prime}}-\mathrm{Ca}_{2} \mathrm{Al}$ compounds are smaller than those of HALS$\mathrm{Ca}_{2} \mathrm{Al}$ and $\mathrm{MP}-\mathrm{Ca}_{2} \mathrm{Al}$, indicating that the number of stacked platelets was decreased due to the co-intercalation. The results show that co-precipitation yields $\mathrm{Ca}_{2} \mathrm{Al}-\mathrm{LDH}$ free of $\mathrm{CaCO}_{3}$ by-product [23].

Figure 3 shows FTIR spectra of all the $\mathrm{H}_{n} \mathrm{M}_{n^{\prime}}$-Ca $\mathrm{a}_{2} \mathrm{Al}$-LDHs. One can observe characteristic stretching-vibration bands of LDHs, for example, the broad band at ca. $3445 \mathrm{~cm}^{-1}$ associated to the $\mathrm{OH}$ groups of interlayer water molecules and brucite-like 


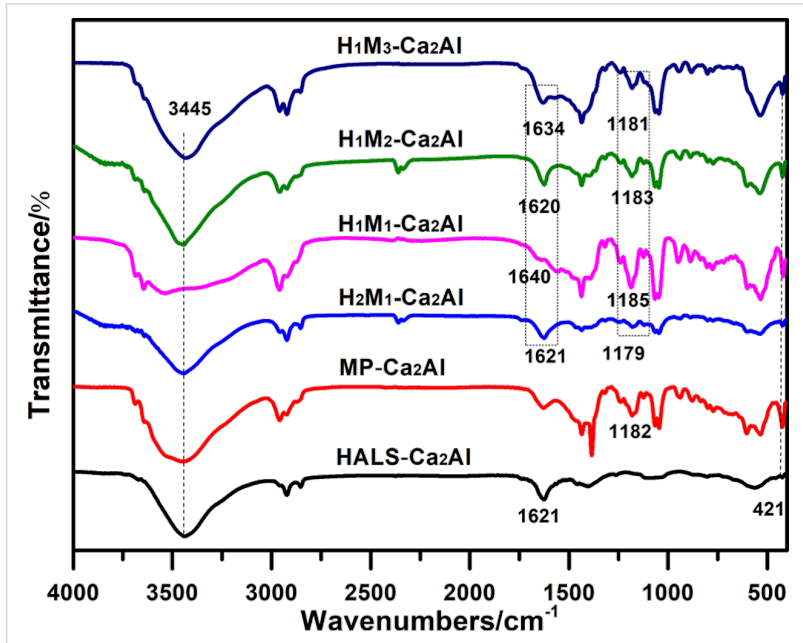

Figure 3: FTIR spectra of different $\mathrm{H}_{n} \mathrm{M}_{n^{\prime}}-\mathrm{Ca}_{2} \mathrm{Al}-\mathrm{LDH}$ samples.

LDH layers. The band at $421 \mathrm{~cm}^{-1}$ is attributed to $\mathrm{O}-\mathrm{M}-\mathrm{O}$ lattice vibrations in $\mathrm{LDH}$, which further proves the formation of a LDH platelet structure. Moreover, for HALS-Ca $2 \mathrm{Al}-\mathrm{LDH}$ and $\mathrm{MP}-\mathrm{Ca}_{2} \mathrm{Al}-\mathrm{LDH}$, the characteristics stretching vibration bands of HALS and MP also occur, such as the carbonyl group of HALS at $1621 \mathrm{~cm}^{-1}(\mathrm{C}=\mathrm{O})$ and the phosphate group of MP at $1181 \mathrm{~cm}^{-1}(\mathrm{P}=\mathrm{O}), 1050 \mathrm{~cm}^{-1}(\mathrm{P}-\mathrm{O}-\mathrm{C})$. Compared with $1645 \mathrm{~cm}^{-1}$ in HALS and $1164 \mathrm{~cm}^{-1}$ in MP-Ca, shifts of $\mathrm{C}=\mathrm{O}$ and $\mathrm{P}=\mathrm{O}$ are observed to $1621 \mathrm{~cm}^{-1}$ in HALS-Ca $\mathrm{Ca}_{2} \mathrm{Al}$ and $1182 \mathrm{~cm}^{-1}$ in $\mathrm{MP}-\mathrm{Ca}_{2} \mathrm{Al}$, respectively, which probably results from the electrostatic interaction between the organic anions and the host sheets of $\mathrm{Ca}_{2} \mathrm{Al}-\mathrm{LDH}$. After co-intercalation of HALS and MP, $\mathrm{H}_{n} \mathrm{M}_{n^{\prime}}-\mathrm{Ca}_{2} \mathrm{Al}$ samples demonstrate all of the characteristic absorption bands of the LDH host together with those of HALS and MP, suggesting the coexistence of active HALS and MP species within $\mathrm{H}_{n} \mathrm{M}_{n^{\prime}}-\mathrm{Ca}_{2} \mathrm{Al}-\mathrm{LDH}$.

Figure 4 presents SEM images of HALS-Ca $2 \mathrm{Al}, \mathrm{MP}-\mathrm{Ca}_{2} \mathrm{Al}$ and $\mathrm{H}_{n} \mathrm{M}_{n^{\prime}}-\mathrm{Ca}_{2} \mathrm{Al}-\mathrm{LDH}$. HALS-Ca $2 \mathrm{Al}$ and $\mathrm{MP}-\mathrm{Ca}_{2} \mathrm{Al}$ show typical platelet-like morphologies. In comparison with $\mathrm{MP}-\mathrm{Ca}_{2} \mathrm{Al}$, HALS- $\mathrm{Ca}_{2} \mathrm{Al}$ exhibits a flattened platelet-like structure and a larger average particle size. For the co-intercalated $\mathrm{H}_{n} \mathrm{M}_{n^{\prime}}$ $\mathrm{Ca}_{2} \mathrm{Al}$, one observes a significant aggregation of $\mathrm{LDH}$ platelets leading to a porous flower-like morphology.

Figure 5 shows the TG and DTA curves of $\mathrm{H}_{n} \mathrm{M}_{n^{\prime}}-\mathrm{Ca}_{2} \mathrm{Al}-\mathrm{LDHs}$ and Table 1 summarizes the corresponding data. In our previous work, the decomposition of HALS and Irganox 1425 molecular anions occurred with an exothermic DTA peak at 300 and $295^{\circ} \mathrm{C}$, respectively $[16,17]$. Here, three major stages of mass loss in the TG curve of $\mathrm{H}_{n} \mathrm{M}_{n^{\prime}}-\mathrm{Ca}_{2} \mathrm{Al}-\mathrm{LDH}$ samples can be observed. The first mass loss up to $180{ }^{\circ} \mathrm{C}$ is assigned to the release of adsorbed water and crystal water; The second one in the range of $180-250^{\circ} \mathrm{C}$ is attributed to the dehydroxylation of the metal-hydroxide layer. The third large mass loss stage corresponding to the decomposition of HALS and MP ions appears at $250-450{ }^{\circ} \mathrm{C}$ with endothermic peaks between 300 and $360{ }^{\circ} \mathrm{C}$ in the DTA curve. The thermal stability of $\mathrm{H}_{n} \mathrm{M}_{n^{\prime}}-\mathrm{Ca}_{2} \mathrm{Al}-\mathrm{LDHs}$ was expressed through the temperatures associated to a certain weight loss (i.e., $T_{25 \%}$ is the temperature at which the sample has lost $25 \mathrm{wt} \%$ ) in Table 1. For intercalated $\mathrm{Ca}_{2} \mathrm{Al}$-LDHs, the thermal oxidative decomposition occurs at temperatures higher than those of HALS and Irganox 1425. Moreover, the co-intercalated $\mathrm{H}_{n} \mathrm{M}_{n^{\prime}}-\mathrm{Ca}_{2} \mathrm{Al}$-LDHs exhibit a higher decomposition temperature than HALS-Ca $2 \mathrm{Al}$ and $\mathrm{MP}-\mathrm{Ca}_{2} \mathrm{Al}$, especially $\mathrm{H}_{1} \mathrm{M}_{2}-\mathrm{Ca}_{2} \mathrm{Al}\left(356{ }^{\circ} \mathrm{C}\right)$. For the co-intercalated $\mathrm{H}_{n} \mathrm{M}_{n^{\prime}}-\mathrm{Ca}_{2} \mathrm{Al}-$ $\mathrm{LDHs}$, the $\mathrm{T}_{25 \%}$ values gradually increase from $257{ }^{\circ} \mathrm{C}$ for $\mathrm{H}_{2} \mathrm{M}_{1}-\mathrm{Ca}_{2} \mathrm{Al}$ to $299{ }^{\circ} \mathrm{C}$ for $\mathrm{H}_{1} \mathrm{M}_{3}-\mathrm{Ca}_{2} \mathrm{Al}$ with an increasing content of $\mathrm{M}$. The above results illustrate that the thermal stability of HALS and MP anions are enhanced after the co-intercalation of both anions into the interlayer region of LDHs.

\begin{tabular}{|c|c|c|c|}
\hline sample & $\begin{array}{l}T_{25 \%} \\
\left({ }^{\circ} \mathrm{C}\right)\end{array}$ & $\begin{array}{l}\text { DTA peak } \\
\left({ }^{\circ} \mathrm{C}\right)\end{array}$ & $\begin{array}{l}\text { residual mass } \\
\text { (wt \%) }\end{array}$ \\
\hline $\mathrm{HALS}-\mathrm{Ca}_{2} \mathrm{Al}$ & 283 & 300 & 55 \\
\hline $\mathrm{MP}-\mathrm{Ca}_{2} \mathrm{Al}$ & 303 & 308 & 51 \\
\hline $\mathrm{H}_{2} \mathrm{M}_{1}-\mathrm{Ca}_{2} \mathrm{Al}$ & 257 & 310 & 45 \\
\hline $\mathrm{H}_{1} \mathrm{M}_{1}-\mathrm{Ca}_{2} \mathrm{Al}$ & 286 & 312 & 49 \\
\hline $\mathrm{H}_{1} \mathrm{M}_{2}-\mathrm{Ca}_{2} \mathrm{Al}$ & 293 & 306,356 & 52 \\
\hline $\mathrm{H}_{1} \mathrm{M}_{3}-\mathrm{Ca}_{2} \mathrm{Al}$ & 299 & 320 & 48 \\
\hline
\end{tabular}

Table 2 lists the element analysis data and the calculated chemical compositions of $\mathrm{H}_{n} \mathrm{M}_{n^{\prime}}-\mathrm{Ca}_{2} \mathrm{Al}$-LDHs analyzed by $\mathrm{CHN}$ elemental analysis for the organic moieties and ICP atomic emission spectrometry for metal cations. The content of interlayer water is determined from the mass loss between 100 and $200{ }^{\circ} \mathrm{C}$ in the TG curves (Figure 5a). The fractions of HALS and MP anions are calculated based on the content of $\mathrm{Al}$ and $\mathrm{C}$ taking into account the charge balance. The molar fractions of the guest anions are close to the feeding ratio, suggesting the ratio between HALS and MP can be adjusted as designed. These results also suggest that both of HALS and MP anions have been co-intercalated into $\mathrm{Ca}_{2} \mathrm{Al}-\mathrm{LDH}$.

\section{Analysis of $\mathrm{H}_{n} \mathrm{M}_{n^{\prime}}-\mathrm{Ca}_{2} \mathrm{Al}-\mathrm{LDHs} / \mathrm{PP}$ composites}

Figure 6 shows XRD patterns of $\mathrm{H}_{n} \mathrm{M}_{n^{\prime}}-\mathrm{Ca}_{2} \mathrm{Al}$-LDHs/PP composites. All samples show the characteristic Bragg reflections of $\alpha$-PP at $12-30^{\circ}$ for (110), (040), (130), (111) and (131)/(041) $d$-spacings. That is, the addition of $\mathrm{H}_{n} \mathrm{M}_{n^{\prime}}-\mathrm{Ca}_{2} \mathrm{Al}$-LDHs has only insignificant influence on the crystallization behavior of PP [24]. For HALS-Ca $2 \mathrm{Al} / \mathrm{PP}$ and MP-Ca $2 \mathrm{Al} / \mathrm{PP}$, the typical 


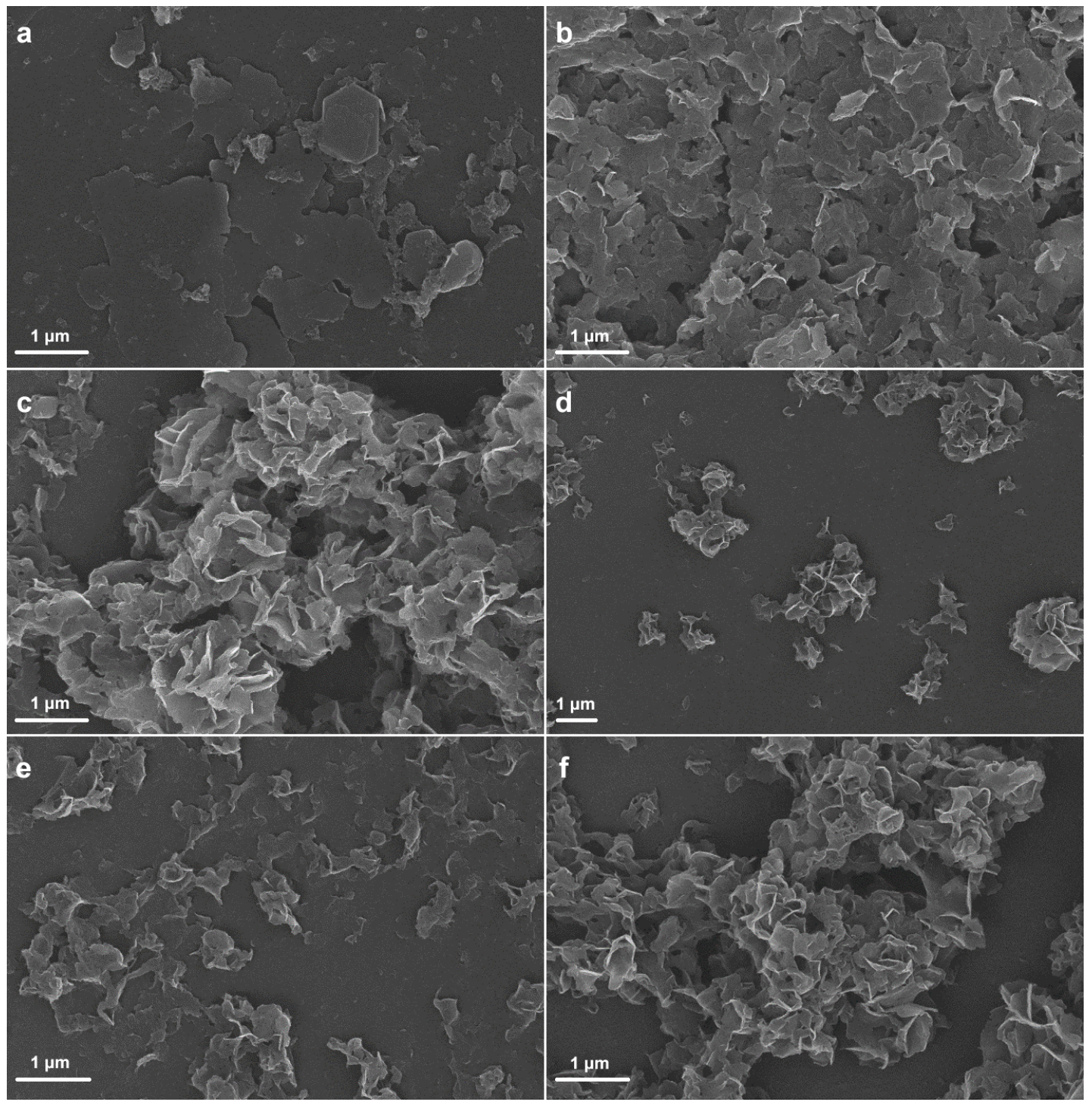

Figure 4: SEM images of (a) HALS-Ca $2 A I$, (b) MP-Ca $a_{2} A l$ and (c) $H_{2} M_{1}-C_{2} A l$, (d) $H_{1} M_{1}-C a_{2} A l$, (e) $H_{1} M_{2}-C_{2} A l$, (f) $H_{1} M_{3}-C a_{2} A l$.
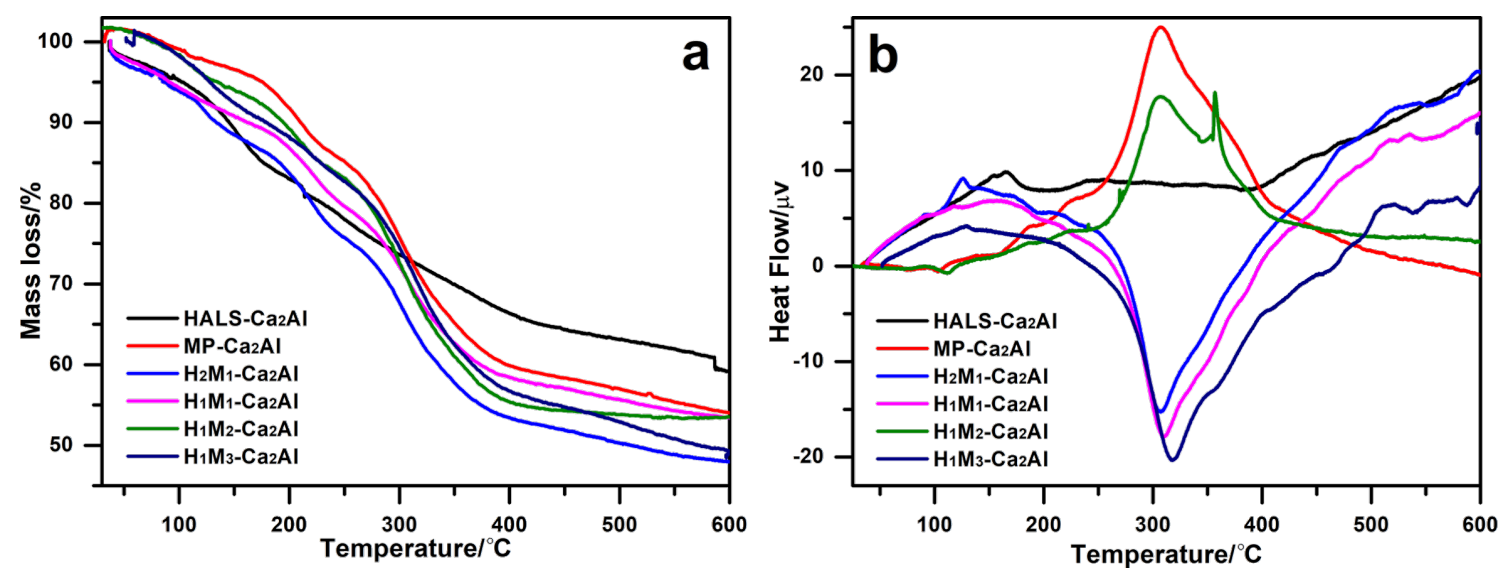

Figure 5: (a) TG and (b) DTA curves of $\mathrm{Ca}_{2} \mathrm{Al}-\mathrm{LDHs}$ : HALS-Ca $2 \mathrm{Al}, \mathrm{MP}-\mathrm{Ca}_{2} \mathrm{Al}, \mathrm{H}_{2} \mathrm{M}_{1}-\mathrm{Ca}_{2} \mathrm{Al}, \mathrm{H}_{1} \mathrm{M}_{1}-\mathrm{Ca}_{2} \mathrm{Al}, \mathrm{H}_{1} \mathrm{M}_{2}-\mathrm{Ca}_{2} \mathrm{Al}$, and $\mathrm{H}_{1} \mathrm{M}_{3}-\mathrm{Ca}_{2} \mathrm{Al}$. 
Table 2: Chemical composition of $\mathrm{H}_{n} \mathrm{M}_{n^{\prime \prime}}-\mathrm{Ca}_{2} \mathrm{Al}-\mathrm{LDH}$ samples.

\begin{tabular}{lllllll} 
sample & $\mathrm{Ca}($ wt \%) & $\mathrm{Al}($ wt \%) & $\mathrm{C}($ wt \%) & $\mathrm{Ca} / \mathrm{Al}$ & $\mathrm{H}_{2} \mathrm{O}$ (wt \%) & chemical composition \\
\hline $\mathrm{HALS}-\mathrm{Ca}{ }_{2} \mathrm{Al}$ & 14.4 & 5.1 & 28.6 & 2.0 & 12.2 & $\mathrm{Ca}_{0.67} \mathrm{Al}_{0.33}(\mathrm{OH})_{2}(\mathrm{HALS})_{0.33} \cdot 1.1 \mathrm{H}_{2} \mathrm{O}$ \\
$\mathrm{MP}-\mathrm{Ca}_{2} \mathrm{Al}$ & 12.9 & 3.5 & 31.4 & 2.1 & 7.3 & $\mathrm{Ca}_{0.68} \mathrm{Al}_{0.32}(\mathrm{OH})_{2}(\mathrm{MP})_{0.32} \cdot 0.85 \mathrm{H}_{2} \mathrm{O}$ \\
$\mathrm{H}_{2} \mathrm{M}_{1}-\mathrm{Ca}_{2} \mathrm{Al}$ & 15.8 & 3.8 & 29.1 & 2.3 & 8.4 & $\mathrm{Ca}_{0.7} \mathrm{Al}_{0.3}(\mathrm{OH})_{2}(\mathrm{HALS})_{0.2}(\mathrm{MP})_{0.1} \cdot 0.68 \mathrm{H}_{2} \mathrm{O}$ \\
$\mathrm{H}_{1} \mathrm{M}_{1}-\mathrm{Ca}_{2} \mathrm{Al}$ & 14.5 & 3.7 & 30.2 & 2.2 & 7.5 & $\mathrm{Ca}_{0.69} \mathrm{Al}_{0.31}(\mathrm{OH})_{2}(\mathrm{HALS})_{0.15}(\mathrm{MP})_{0.16} \cdot 0.72 \mathrm{H}_{2} \mathrm{O}$ \\
$\mathrm{H}_{1} \mathrm{M}_{2}-\mathrm{Ca}_{2} \mathrm{Al}$ & 14.9 & 3.3 & 31.6 & 2.3 & 9.4 & $\mathrm{Ca}_{0.7} \mathrm{Al}_{0.3}(\mathrm{OH})_{2}(\mathrm{HALS})_{0.1}(\mathrm{MP})_{0.2} \cdot 0.83 \mathrm{H}_{2} \mathrm{O}$ \\
$\mathrm{H}_{1} \mathrm{M}_{3}-\mathrm{Ca}_{2} \mathrm{Al}$ & 16.5 & 3.9 & 29.5 & 2.5 & 8.0 & $\mathrm{Ca}_{0.72} \mathrm{Al}_{0.28}(\mathrm{OH})_{2}(\mathrm{HALS})_{0.07}(\mathrm{MP})_{0.21} \cdot 0.66 \mathrm{H}_{2} \mathrm{O}$
\end{tabular}

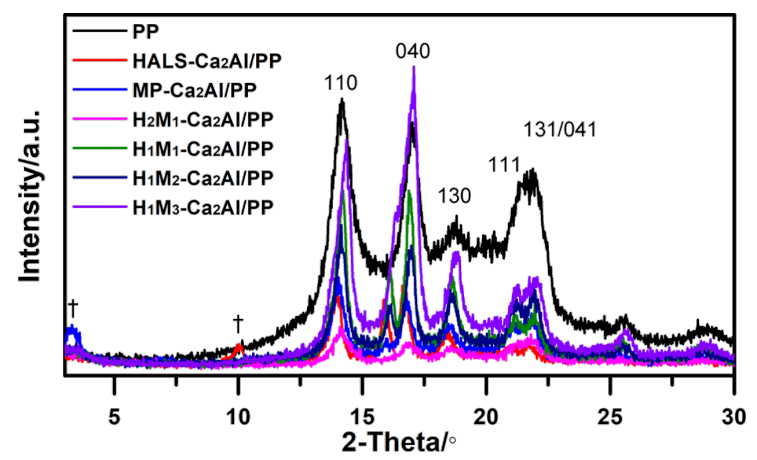

Figure 6: Powder X-ray diffraction pattern of $\mathrm{H}_{n} \mathrm{M}_{n^{\prime}}-\mathrm{Ca}_{2} \mathrm{Al} / \mathrm{PP}$ composites. $\mathrm{LDH}$ reflection peaks were marked with " $†$ ". reflection (002) peaks of HALS-Ca $2 \mathrm{Al}$ and MP-Ca ${ }_{2} \mathrm{Al}$ clearly appear (marked with " $\dagger$ ") with an increase in spacing from 0.77 to $0.88 \mathrm{~nm}$ for HALS-Ca $2 \mathrm{Al}$ and from 2.52 to $2.68 \mathrm{~nm}$ for $\mathrm{MP}-\mathrm{Ca}_{2} \mathrm{Al}$. Probably, the PP chains were intercalated into the LDH gap structure to produce a polymer-intercalated nanocomposite [25]. Yet, none of the diffraction peaks of the co-intercalated $\mathrm{H}_{n} \mathrm{M}_{n^{\prime}} \mathrm{Ca}_{2} \mathrm{Al}$ hybrid LDHs is observed in the resulting $\mathrm{H}_{n} \mathrm{M}_{n^{\prime}}-\mathrm{Ca}_{2} \mathrm{Al} / \mathrm{PP}$ composites, suggesting a high dispersion of LDH nanoparticles in the composite.

Figure 7a depicts the FTIR spectra of $\mathrm{H}_{n} \mathrm{M}_{n^{\prime}}-\mathrm{Ca}_{2} \mathrm{Al} / \mathrm{PP}$ composites in absorbance mode. Here, all composites present the characteristic bands of PP: 2950, 2915, 2868, 2837, 1454, and $1375 \mathrm{~cm}^{-1}$. Some additional bands assigned to LDHs and guest
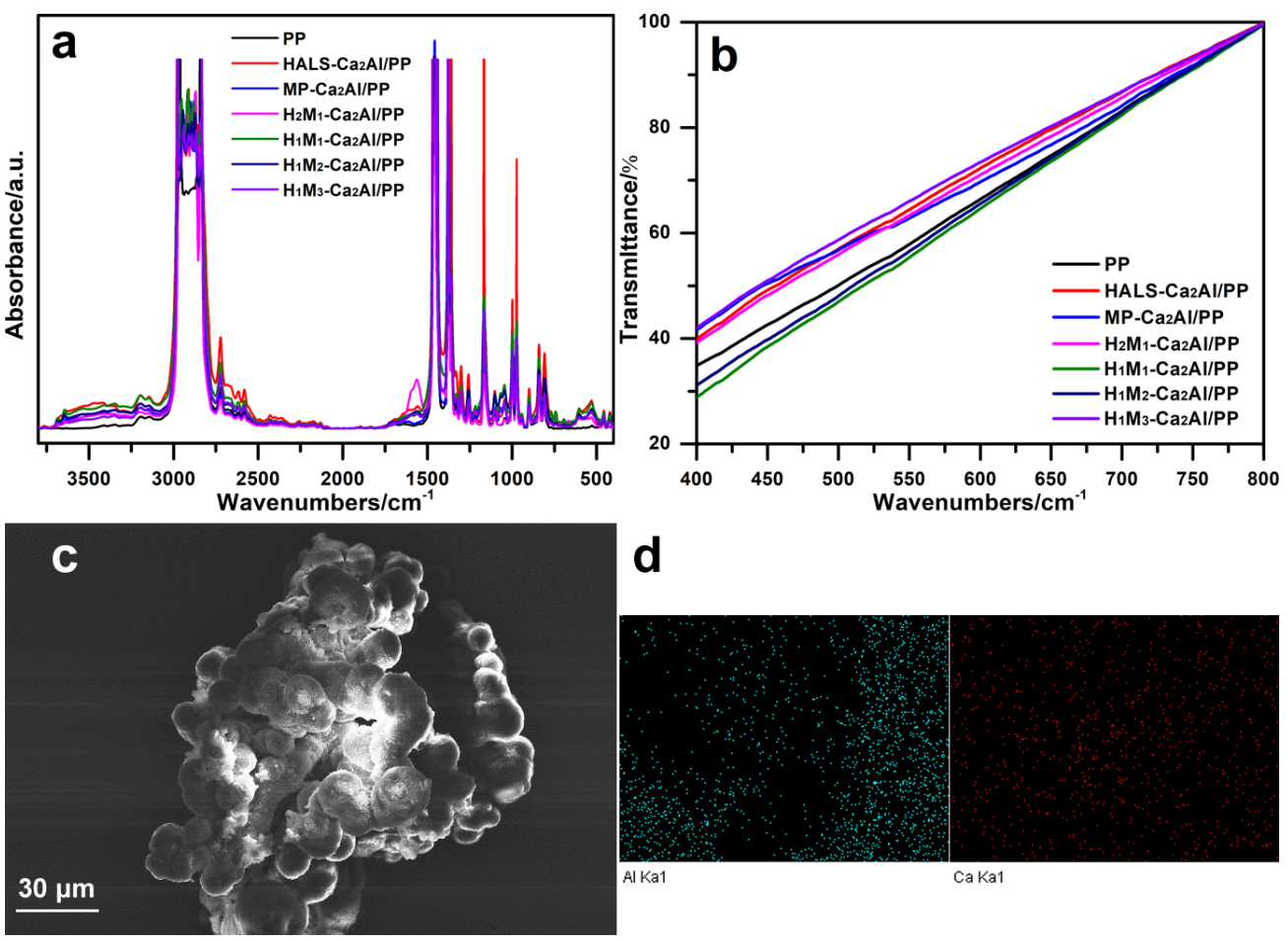

d

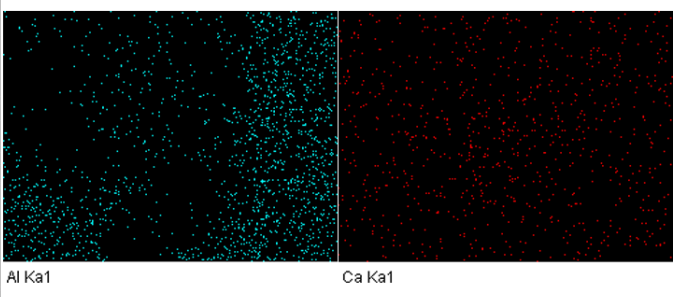

Figure 7: (a) FTIR spectra and (b) visible-light transmittance spectra of $\mathrm{Ca}_{2} \mathrm{Al} / \mathrm{PP}$ composites. (c) SEM image and (d) Al (left) and Ca (right) element mapping of the $\mathrm{H}_{1} \mathrm{M}_{1}-\mathrm{Ca}_{2} \mathrm{Al} / \mathrm{PP}$ composite. 
anions are also observed after addition of $\mathrm{H}_{n} \mathrm{M}_{n^{\prime}}-\mathrm{Ca}_{2} \mathrm{Al}$-LDHs. Figure $7 \mathrm{~b}$ demonstrates the visible-light transmittance of $\mathrm{H}_{n} \mathrm{M}_{n^{\prime}}-\mathrm{Ca}_{2} \mathrm{Al}-\mathrm{LDH} / \mathrm{PP}$ composite films, which is one of crucial properties of the PP products. All the samples show a similar trend demonstrating that there is a good dispersion of $\mathrm{Ca}_{2} \mathrm{Al}-$ LDHs in the PP matrix without affecting its visible-light transmission. Figure $7 \mathrm{c}, \mathrm{d}$ displays the surface morphology and element distribution of $\mathrm{H}_{1} \mathrm{M}_{1}-\mathrm{Ca}_{2} \mathrm{Al} / \mathrm{PP}$ composites from SEM and element mapping. Consistent with PP free of filler, a spherical structure is observed for $\mathrm{Ca}_{2} \mathrm{Al} / \mathrm{PP}$ composites and $\mathrm{Al}$ (left) and $\mathrm{Ca}$ (right) elements are homogenously distributed in the $\mathrm{H}_{1} \mathrm{M}_{1}$ $\mathrm{Ca}_{2} \mathrm{Al} / \mathrm{PP}$ composite films. All results confirm that $\mathrm{Ca}_{2} \mathrm{Al}-\mathrm{LDH}$ particles are well dispersed in the PP matrix and have no negative effect on the structure and morphology.

\section{Performance of $\mathrm{H}_{n} \mathrm{M}_{n^{\prime}}-\mathrm{Ca}_{2} \mathrm{Al} / \mathrm{PP}$ composites}

Figure 8a shows the thermal decomposition of $\mathrm{H}_{n} \mathrm{M}_{n^{\prime}}-\mathrm{Ca}_{2} \mathrm{Al} / \mathrm{PP}$ composites measured by TG-DTA. The thermal decomposition observed for $\mathrm{Ca}_{2} \mathrm{Al} / \mathrm{PP}$ composites is comparable to that of $\mathrm{PP}$ free of filler, and the main decomposition process for all sam- ples occurs between 250 and $450{ }^{\circ} \mathrm{C}$. The incorporation of $\mathrm{H}_{n} \mathrm{M}_{n^{\prime}}-\mathrm{Ca}_{2} \mathrm{Al}-\mathrm{LDH}$ is found to increase the onset temperature ( $T_{\text {onset }}$ ) of the initial degradation process. The onset values for co-intercalated $\mathrm{H}_{n} \mathrm{M}_{n^{\prime}}-\mathrm{Ca}_{2} \mathrm{Al} / \mathrm{PP}$ composites are higher $T_{\text {onset }}$ in the range of $336-367^{\circ} \mathrm{C}$ than those of PP free of filler $\left(265^{\circ} \mathrm{C}\right)$, HALS-Ca $2 \mathrm{Al} / \mathrm{PP}\left(335^{\circ} \mathrm{C}\right)$ and MP-Ca $2 \mathrm{Al} / \mathrm{PP}\left(333^{\circ} \mathrm{C}\right)$. However, the onset temperature of co-intercalated $\mathrm{H}_{n} \mathrm{M}_{n^{\prime}}-\mathrm{Ca}_{2} \mathrm{Al} / \mathrm{PP}$ does not increase with the percentage of $\mathrm{M} . \mathrm{H}_{2} \mathrm{M}_{1}-\mathrm{Ca}_{2} \mathrm{Al} / \mathrm{PP}$ has the highest $T_{\text {onset }}$ value. Moreover, with the addition of $\mathrm{H}_{n} \mathrm{M}_{n^{\prime}}-\mathrm{Ca}_{2} \mathrm{Al}-\mathrm{LDHs}$, the amount of residue is also increased, the promotion of the carbonization process leads to a better flame retardancy of $\mathrm{Ca}_{2} \mathrm{Al} / \mathrm{PP}$ composites. As a result, the thermal stability of $\mathrm{H}_{n} \mathrm{M}_{n^{\prime}}-\mathrm{Ca}_{2} \mathrm{Al} / \mathrm{PP}$ composites is obviously improved.

Figure $8 \mathrm{~b}$ shows the thermal degradation of $\mathrm{H}_{n} \mathrm{M}_{n^{\prime}}-\mathrm{Ca}_{2} \mathrm{Al} / \mathrm{PP}$ composite films at $150{ }^{\circ} \mathrm{C}$ as a function of aging time, recorded by FTIR. With increasing thermal-aging time, the intensity of the carbonyl peak of the PP film (without filler) significantly increases in the range of $1810-1660 \mathrm{~cm}^{-1}$, accompanied by
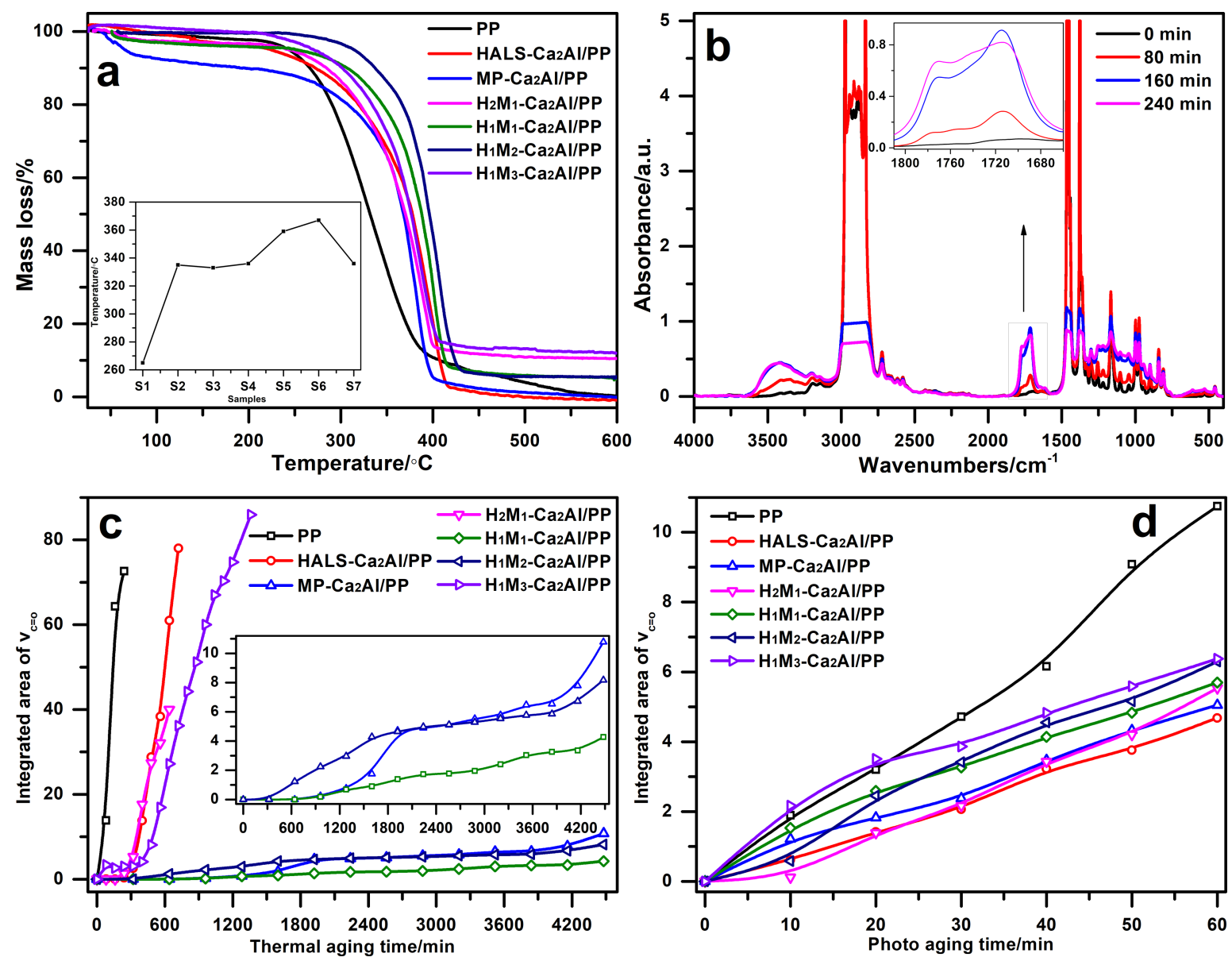

Figure 8: (a) TGA curves of $\mathrm{H}_{n} \mathrm{M}_{n^{\prime}}$-Ca $\mathrm{Ca}_{2} \mathrm{Al} / \mathrm{PP}$ composites. (b) FTIR spectra of PP after different periods of thermal aging. (c) Thermal aging and (d) photo-oxidation aging of $\mathrm{H}_{n} \mathrm{M}_{n^{\prime}}-\mathrm{Ca}_{2} \mathrm{Al} / \mathrm{PP}$ films. 
changes in shape and position. Here, the integrated area of the carbonyl band is measured to quantitatively analyze the degradation degree of $\mathrm{H}_{n} \mathrm{M}_{n^{\prime}}-\mathrm{Ca}_{2} \mathrm{Al} / \mathrm{PP}$ composite films. Figure $8 \mathrm{c}$ shows the integrated area as a function of the aging time. Two things can be noted: (1) PP, HALS-Ca $2 \mathrm{Al} / \mathrm{PP}, \mathrm{H}_{2} \mathrm{M}_{1}-\mathrm{Ca}_{2} \mathrm{Al} / \mathrm{PP}$ and $\mathrm{H}_{1} \mathrm{M}_{3}-\mathrm{Ca}_{2} \mathrm{Al} / \mathrm{PP}$ films, during rapid thermal aging, completely break after less than $1600 \mathrm{~min}$. (2) $\mathrm{MP}-\mathrm{Ca}_{2} \mathrm{Al} / \mathrm{PP}$, $\mathrm{H}_{1} \mathrm{M}_{1}-\mathrm{Ca}_{2} \mathrm{Al} / \mathrm{PP}$ and $\mathrm{H}_{1} \mathrm{M}_{2}-\mathrm{Ca}_{2} \mathrm{Al} / \mathrm{PP}$ films exhibit a good stability against thermal aging, and their appearance remains intact after $4500 \mathrm{~min}$ at $150{ }^{\circ} \mathrm{C}$. The additive MP-Ca is an excellent protection against thermal degradation, while HALS is a photo-oxidation stabilizer. With the same amount of $\mathrm{H}$ and $\mathrm{M}$, the composite $\mathrm{H}_{1} \mathrm{M}_{1}-\mathrm{Ca}_{2} \mathrm{Al} / \mathrm{PP}$ shows the best thermal stability among all intercalated $\mathrm{Ca}_{2} \mathrm{Al}$-LDHs. Also, the ratio between HALS and MP can be used to slightly tune the thermal properties of the LDH/PP composites.

Figure 8d displays the photo-oxidation degradation of $\mathrm{H}_{n} \mathrm{M}_{n^{\prime}}$ $\mathrm{Ca}_{2} \mathrm{Al} / \mathrm{PP}$ composite films under UV irradiation. The integrated area in the range of $1810-1660 \mathrm{~cm}^{-1}$ for all samples becomes larger with increasing UV exposure time. In comparison with PP free of filler, the addition of $\mathrm{H}_{n} \mathrm{M}_{n^{\prime}}-\mathrm{Ca}_{2} \mathrm{Al}-\mathrm{LDHs}$ enhances the photo-oxidation stability. The photo-oxidation stability is in the following order: HALS-Ca $2 \mathrm{Al} / \mathrm{PP}>\mathrm{H}_{2} \mathrm{M}_{1}-\mathrm{Ca}_{2} \mathrm{Al} / \mathrm{PP}>$ $\mathrm{MP}-\mathrm{Ca}_{2} \mathrm{Al} / \mathrm{PP}>\mathrm{H}_{1} \mathrm{M}_{1}-\mathrm{Ca}_{2} \mathrm{Al} / \mathrm{PP}>\mathrm{H}_{1} \mathrm{M}_{2}-\mathrm{Ca}_{2} \mathrm{Al} / \mathrm{PP}>\mathrm{H}_{1} \mathrm{M}_{3}-$ $\mathrm{Ca}_{2} \mathrm{Al} / \mathrm{PP}$. The different co-intercalated $\mathrm{H}_{n} \mathrm{M}_{n^{\prime}}-\mathrm{Ca}_{2} \mathrm{Al}$-LDHs are found to enhance the thermal and photo-oxidation stability of $\mathrm{H}_{n} \mathrm{M}_{n^{\prime}}-\mathrm{Ca}_{2} \mathrm{Al} / \mathrm{PP}$ composite films, and the co-intercalated $\mathrm{LDH} / \mathrm{PP}$ composite films have better overall performances compared with the systems intercalated with HALS or MP only.

\section{Conclusion}

In this work, we have successfully co-intercalated a hindered amine light stabilizer (HALS) and a hindered phenolic antioxidant (MP) into the interlayer region of $\mathrm{Ca}_{2} \mathrm{Al}-\mathrm{LDHs}$ with different molar ratios through coprecipitation. The concomitant intercalation of HALS and MP significantly enhances the thermal stability of the powders due to the host-guest interactions between guest anions and the host LDH. Subsequently a series of $\mathrm{H}_{n} \mathrm{M}_{n^{\prime}}-\mathrm{Ca}_{2} \mathrm{Al} / \mathrm{PP}$ composite films was prepared. The results show that the addition of $\mathrm{H}_{n} \mathrm{M}_{n^{\prime}}-\mathrm{Ca}_{2} \mathrm{Al}-\mathrm{LDH}$ has no negative effect on the crystallization behavior of PP, while it improves significantly the stability of the composites against thermal degradation and photo-oxidation. Undoubtedly, the co-intercalation method for LDH framework will open a way to design and fabricate multifunctional additives for polymer composites.

\section{Experimental Chemicals}

Succinic anhydride, tetramethylpiperidinamine, dioxane, ether, $\mathrm{Ca}\left(\mathrm{NO}_{3}\right)_{2} \cdot 4 \mathrm{H}_{2} \mathrm{O}, \mathrm{Al}\left(\mathrm{NO}_{3}\right)_{3} \cdot 9 \mathrm{H}_{2} \mathrm{O}, \mathrm{NaOH}, \mathrm{C}_{2} \mathrm{H}_{5} \mathrm{OH}$,
$\mathrm{CH}_{3} \mathrm{COCH}_{3}$, xylene and hexane were directly used as received from Beijing Chemical Co. Limited. Deionized water was employed in all experiments. Polypropylene (PP1300, melting index: $1.5 \mathrm{~g} / 10 \mathrm{~min}$; melting point: $164-170{ }^{\circ} \mathrm{C}$; density: $0.91 \mathrm{~g} \cdot \mathrm{cm}^{-3}$ ), and Irganox 1425 were supplied from Beijing Yanshan Petrochemical Co. Ltd., China.

\section{Fabrication of HALS}

The HALS was synthesized as reported [16]. Typically, succinic anhydride $(15 \mathrm{mmol})$ was dissolved into $10 \mathrm{~mL}$ of dioxane at $80{ }^{\circ} \mathrm{C}$ under vigorous stirring, and tetramethylpiperidinamine $(15 \mathrm{mmol})$ in $10 \mathrm{~mL}$ of dioxane was dropwise added. The solution was kept at $80{ }^{\circ} \mathrm{C}$ for $40 \mathrm{~min}$. The product was washed three times using dioxane and ether. Finally, the powdered product HALS was collected after vacuum filtration.

\section{Fabrication of $\mathrm{H}_{n} \mathrm{M}_{n^{\prime}}-\mathrm{Ca}_{2} \mathrm{Al}$-LDHs}

The HALS and MP co-intercalated LDHs $\left(\mathrm{H}_{n} \mathrm{M}_{n^{\prime}}-\mathrm{Ca}_{2} \mathrm{Al}-\right.$ LDHs) were prepared through coprecipitation with different $\mathrm{H} / \mathrm{M}$ molar ratios of $2: 1,1: 1,1: 2,1: 3$. For $\mathrm{H}_{1} \mathrm{M}_{1}-\mathrm{Ca}_{2} \mathrm{Al}$, HALS (3.072 g, $12 \mathrm{mmol})$ and Irganox 1425 (4.17 g, $6 \mathrm{mmol})$ were dissolved in $240 \mathrm{~mL}$ of ethanol/water $(3: 1, \mathrm{v} / \mathrm{v})$. A solution containing $0.100 \mathrm{~mol} \cdot \mathrm{L}^{-1} \mathrm{Al}\left(\mathrm{NO}_{3}\right)_{3} \cdot 9 \mathrm{H}_{2} \mathrm{O}$ and $1.40 \mathrm{~mol} \cdot \mathrm{L}^{-1} \mathrm{NaOH}$ was added dropwise to the above HALS/MP-Ca solution at room temperature under vigorous stirring in nitrogen atmosphere. The $\mathrm{pH}$ value in the reaction system was maintained at $\mathrm{pH} 10$ after finishing the addition, and the reaction was kept for another $12 \mathrm{~h}$. The suspension was centrifuged and washed with $60 \%$ ethanol solution until $\mathrm{pH} 7$. The resulting slurry was further washed twice with acetone with surface modification and then was used for the preparation of $\mathrm{H}_{1} \mathrm{M}_{1}-\mathrm{Ca}_{2} \mathrm{Al} / \mathrm{PP}$ composites. To obtain the $\mathrm{H}_{1} \mathrm{M}_{1}-\mathrm{Ca}_{2} \mathrm{Al}$ powder, part of the slurry was dried in an oven at $80{ }^{\circ} \mathrm{C}$ for $24 \mathrm{~h}$. Co-intercalated $\mathrm{H}_{n} \mathrm{M}_{n^{\prime}}-\mathrm{Ca}_{2} \mathrm{Al}$ with different molar ratios and $\mathrm{MP}-\mathrm{Ca}_{2} \mathrm{Al}$ were obtained through a similar process. Besides, HALS- $\mathrm{Ca}_{2} \mathrm{Al}$ as the reference was prepared similarly with a metal solution of $\mathrm{Ca}\left(\mathrm{NO}_{3}\right)_{2} \cdot 4 \mathrm{H}_{2} \mathrm{O}$ and $\mathrm{Al}\left(\mathrm{NO}_{3}\right)_{3} \cdot 9 \mathrm{H}_{2} \mathrm{O}$.

\section{Fabrication of $\mathrm{H}_{n} \mathrm{M}_{n^{\prime}}-\mathrm{Ca}_{2} \mathrm{Al} / \mathrm{PP}$ composites}

A series of $\mathrm{H}_{n} \mathrm{M}_{n^{\prime}}-\mathrm{Ca}_{2} \mathrm{Al} / \mathrm{PP}$ composites was fabricated through solvent mixing with the same mass loading of $4.0 \mathrm{wt} \%$ compared with pure PP [26]. For the example of $\mathrm{H}_{1} \mathrm{M}_{1}-\mathrm{Ca}_{2} \mathrm{Al} / \mathrm{PP}$, $6.36 \mathrm{~g}$ of $\mathrm{H}_{1} \mathrm{M}_{1}-\mathrm{Ca}_{2} \mathrm{Al}$ slurry (solid content: $6.30 \mathrm{wt} \%$ ) was dispersed in $100 \mathrm{~mL}$ xylene containing $10.0 \mathrm{~g}$ PP and the suspension was heated to $140{ }^{\circ} \mathrm{C}$ in an oil bath under vigorous stirring for $3 \mathrm{~h}$. The resulting suspension was immediately transferred into $50 \mathrm{~mL}$ hexane solvent and then cooled down to $25^{\circ} \mathrm{C}$. Finally, the solid product was collected after drying to constant weight at $80{ }^{\circ} \mathrm{C}$. For further analyses, the $\mathrm{H}_{1} \mathrm{M}_{1}$ - 
$\mathrm{Ca}_{2} \mathrm{Al} / \mathrm{PP}$ composite was pressed into a composite film by Teflon sheets at $170{ }^{\circ} \mathrm{C}$ and the thickness was controlled to be ca. $0.1 \mathrm{~mm}$. Composites of other LDHs with PP (HALS-Ca $a_{2} \mathrm{Al} /$ PP, MP-Ca $2 \mathrm{Al} / \mathrm{PP}, \mathrm{H}_{2} \mathrm{M}_{1}-\mathrm{Ca}_{2} \mathrm{Al} / \mathrm{PP}, \mathrm{H}_{1} \mathrm{M}_{2}-\mathrm{Ca}_{2} \mathrm{Al} / \mathrm{PP}, \mathrm{H}_{1} \mathrm{M}_{3}-$ $\mathrm{Ca}_{2} \mathrm{Al} / \mathrm{PP}$ ) were prepared following a similar process using the required amount of LDH slurry.

\section{Characterization}

Powder X-ray diffraction (XRD) measurements were performed on a Shimadzu XRD-6000 X-ray diffractometer with a wavelength of $0.154 \mathrm{~nm}$ at $40 \mathrm{kV}$ and $30 \mathrm{~mA}$ in a $2 \theta$ range of $3-70^{\circ}$ at $10^{\circ} \cdot \mathrm{min}^{-1}$. Fourier-transform infrared (FTIR) spectra were recorded on a Bruker Vector 22 infrared spectrophotometer with $\mathrm{KBr}$ pellets (sample/KBr of 1:100 by weight) or thin films. Thermogravimetry and differential thermal analysis (TG-DTA) was performed on a PCT-IA instrument in the range of 25 to $700{ }^{\circ} \mathrm{C}$ at $5^{\circ} \mathrm{C} \cdot \mathrm{min}^{-1}$ under flowing air. Scanning electron microscopy (SEM) images were taken with a Zeiss scanning electron microscope by dropping dilute ethanol suspension at room temperature. Elemental analysis for metal elements ( $\mathrm{Ca}$ and $\mathrm{Al}$ ) was carried out on a Shimadzu ICPS-7500 inductively coupled plasma (ICP) atomic emission spectrometer. About $30 \mathrm{mg}$ of the samples was dissolved in a few drops of concentrated nitric acid (65\%) and diluted to $10 \mathrm{~mL}$ using water. CHN elemental analysis was carried out on a Vario EL III, Elementar instrument. The content of water in the samples was obtained by thermogravimetry. The UV-vis spectra in the range of 200 to $800 \mathrm{~nm}$ were collected by using a Shimadzu UV-2501PC spectrophotometer.

\section{Stability evaluation of $\mathrm{H}_{n} \mathrm{M}_{n^{\prime}}-\mathrm{Ca}_{2} \mathrm{Al} / \mathrm{PP}$ composites}

Here, two methods were employed to evaluate the thermal stability of $\mathrm{H}_{n} \mathrm{M}_{n^{\prime}}-\mathrm{Ca}_{2} \mathrm{Al} / \mathrm{PP}$ composites. One way was to examine the composite samples with TG-DTA, for example, ca. $7 \mathrm{mg}$ of the samples was heated from 25 to $600{ }^{\circ} \mathrm{C}$ at $10{ }^{\circ} \mathrm{C} \cdot \mathrm{min}^{-1}$ in flowing air. The other was to perform an accelerated thermal aging test in an oven [15]. For this, $\mathrm{H}_{n} \mathrm{M}_{n^{\prime-}}$ $\mathrm{Ca}_{2} \mathrm{Al} / \mathrm{PP}$ composite films were tailored to a size of $20 \times 20 \times 0.1 \mathrm{~mm}$ and thermally aged at $150^{\circ} \mathrm{C}$. Every $80 \mathrm{~min}$, the composition was monitored by FTIR. For the quantitative analysis of the degradation, the integrated area of peaks in the range of $1810-1660 \mathrm{~cm}^{-1}$, assigned to carbonyl groups was used.

The photo stability of $\mathrm{H}_{n} \mathrm{M}_{n^{\prime}}-\mathrm{Ca}_{2} \mathrm{Al} / \mathrm{PP}$ composites $(20 \times 20 \times 0.1 \mathrm{~mm})$ was examined in an accelerated photoaging instrument with an ultraviolet high-pressure mercury lamp $\left(P=100 \mathrm{~W}, \lambda_{\max }=360 \mathrm{~nm}\right)$ and the degradation degree was monitored every 5 min by FTIR [27]. The data processing method was the same as during the thermal aging.

\section{Acknowledgements}

This work is supported by the National Natural Science Foundation of China, the Fundamental Research Funds for the Central Universities (JD1716), and Program for Changjiang Scholars and Innovative Research Team in University (No. IRT1205). Prof. Feng would like to thank the guestprofessor funding provided by the Université Clermont Auvergne.

\section{ORCID ${ }^{\circledR} \mathrm{iDs}$}

Fabrice Leroux - https://orcid.org/0000-0002-4671-9630 Yongjun Feng - https://orcid.org/0000-0001-9254-6219

\section{References}

1. Haidasz, E. A.; Meng, D.; Amorati, R.; Baschieri, A.; Ingold, K. U.; Valgimigli, L.; Pratt, D. A. J. Am. Chem. Soc. 2016, 138, 5290-5298. doi:10.1021/jacs.6b00677

2. Gryn'ova, G.; Ingold, K. U.; Coote, M. L. J. Am. Chem. Soc. 2012, 134, 12979-12988. doi:10.1021/ja3006379

3. Yousif, E.; Haddad, R. SpringerPlus 2013, 2, 398. doi:10.1186/2193-1801-2-398

4. Zhang, G.; Nam, C.; Chung, T. C. M.; Petersson, L.; Hillborg, H. Macromolecules 2017, 50, 7041-7051. doi:10.1021/acs.macromol.7b01235

5. Gijsman, P. Polym. Degrad. Stab. 2017, 145, 2-10. doi:10.1016/j.polymdegradstab.2017.05.012

6. Manteghi, A.; Ahmadi, S.; Arabi, H. Polymer 2016, 104, 31-39. doi:10.1016/j.polymer.2016.09.075

7. Sanchez, C.; Julián, B.; Belleville, P.; Popall, M. J. Mater. Chem. 2005, 15, 3559-3592. doi:10.1039/b509097k

8. Deligiannakis, Y.; Sotiriou, G. A.; Pratsinis, S. E. ACS Appl. Mater. Interfaces 2012, 4, 6609-6617. doi:10.1021/am301751s

9. Bu, J.; Huang, X.; Li, S.; Jiang, P. Carbon 2016, 106, 218-227. doi:10.1016/j.carbon.2016.05.020

10. Dintcheva, N. T.; Arrigo, R.; Gambarotti, C.; Carroccio, S.; Coiai, S.; Filippone, G. J. Appl. Polym. Sci. 2015, 132, 42420. doi:10.1002/app.42420

11. Wang, Q.; O'Hare, D. Chem. Rev. 2012, 112, 4124-4155. doi:10.1021/cr200434v

12. Taviot-Guého, C.; Prévot, V.; Forano, C.; Renaudin, G.; Mousty, C.; Leroux, F. Adv. Funct. Mater. 2018, 28, 1703868. doi:10.1002/adfm.201703868

13. Basu, D.; Das, A.; Stöckelhuber, K. W.; Wagenknecht, U.; Heinrich, G. Prog. Polym. Sci. 2014, 39, 594-626. doi:10.1016/j.progpolymsci.2013.07.011

14. Mao, N.; Zhou, C. H.; Tong, D. S.; Yu, W. H.; Cynthia Lin, C. X. Appl. Clay Sci. 2017, 144, 60-78. doi:10.1016/j.clay.2017.04.021

15. Feng, Y.; Jiang, Y.; Huang, Q.; Chen, S.; Zhang, F.; Tang, P.; Li, D. Ind. Eng. Chem. Res. 2014, 53, 2287-2292. doi:10.1021/ie403643v

16. Zhang, Q.; Jiao, Q.; Leroux, F.; Tang, P.; Li, D.; Feng, Y. Polym. Degrad. Stab. 2017, 140, 9-16. doi:10.1016/j.polymdegradstab.2017.04.012

17. Zhang, Q.; Leroux, F.; Tang, P.; Li, D.; Feng, Y. Polym. Degrad. Stab. 2018, 154, 55-61. doi:10.1016/j.polymdegradstab.2018.05.027 
18. Beißmann, S.; Reisinger, M.; Grabmayer, K.; Wallner, G.; Nitsche, D.; Buchberger, W. Polym. Degrad. Stab. 2014, 110, 498-508.

doi:10.1016/j.polymdegradstab.2014.09.020

19. Maringer, L.; Roiser, L.; Wallner, G.; Nitsche, D.; Buchberger, W. Polym. Degrad. Stab. 2016, 131, 91-97. doi:10.1016/j.polymdegradstab.2016.07.007

20. Kotal, M.; Bhowmick, A. K. Prog. Polym. Sci. 2015, 51, 127-187. doi:10.1016/j.progpolymsci.2015.10.001

21. Liu, M.; Jia, Z.; Jia, D.; Zhou, C. Prog. Polym. Sci. 2014, 39, 1498-1525. doi:10.1016/j.progpolymsci.2014.04.004

22. Tsai, T.-Y.; Bunekar, N. RSC Adv. 2016, 6, 65291-65298. doi:10.1039/c6ra15790d

23. Xu, S.; Zhang, B.; Chen, Z.; Yu, J.; Evans, D. G.; Zhang, F. Ind. Eng. Chem. Res. 2011, 50, 6567-6572. doi:10.1021/ie102135k

24. Lonkar, S. P.; Singh, R. P. Thermochim. Acta 2009, 491, 63-70. doi:10.1016/j.tca.2009.03.002

25. Zhang, Q.; Jiao, Q.; Leroux, F.; Tang, P.; Li, D.; Feng, Y. New J. Chem. 2017, 41, 2364-2371. doi:10.1039/c6nj03544b

26. Gao, Y.; Wu, J.; Zhang, Z.; Jin, R.; Zhang, X.; Yan, X.; Umar, A.; Guo, Z.; Wang, Q. J. Mater. Chem. A 2013, 1, 9928-9934. doi:10.1039/c3ta11695f

27. Li, D.; Qian, L.; Feng, Y.; Feng, J.; Tang, P.; Yang, L. ACS Appl. Mater. Interfaces 2014, 6, 20603-20611. doi:10.1021/am506696k

\section{License and Terms}

This is an Open Access article under the terms of the Creative Commons Attribution License (http://creativecommons.org/licenses/by/4.0). Please note that the reuse, redistribution and reproduction in particular requires that the authors and source are credited.

The license is subject to the Beilstein Journal of Nanotechnology terms and conditions: (https://www.beilstein-journals.org/bjnano)

The definitive version of this article is the electronic one which can be found at: doi:10.3762/bjnano.9.277 